\title{
Murray F. Brennan, Cristina R. Antonescu, Robert G. Maki: Management of soft tissue sarcoma
}

\author{
Springer, New York, ISBN 978-1-4614-5003-0, Hardcover. €158.20 (Springer)
}

\author{
Robert U. Ashford
}

Received: 8 July 2014 / Accepted: 9 July 2014 / Published online: 20 July 2014

(C) Springer-Verlag France 2014

This is an impressive book. Written by a surgeon, a pathologist and an oncologist, the book draws heavily on the Memorial Sloan-Kettering Cancer Center soft tissue sarcoma (STS) database. This prospectively acquired database, established by the senior author in 1982, now includes data on over 8,000 soft tissue sarcoma patients.

The book features three introductory chapters on incidence and genetic factors, natural history of STSs and general treatment principles.

The majority of the book is on management by histopathology. For each histopathological subtype, there is a review of management including imaging, diagnosis, natural history, treatment, radiation therapy, metastatic disease, adjuvant therapy, recurrence, outcome and references.
This makes the book easy to read and an effective reference source. The book is extensively referenced.

There is a further section on benign and less-aggressive lesions. Pleasingly there is a detailed chapter on Desmoid Tumours and a chapter on soft tissue sarcomas more common in Children.

Whilst this book will not appeal to the general orthopaedic surgeon, it is a book that should be in the library of any sarcoma unit and will appeal to the sub-specialist in Orthopaedic Oncology.

Conflict of interest Mr. Ashford has no conflicts of interest. 